\title{
IMPROVING STUDENTS' SPEAKING ABILITY BY USING INTERVIEW TECHNIQUE AT GRADE XI SMA NEGERI 3 PADANGSIDIMPUAN
}

\author{
By: Nurmadinah Hasibuan
}

\begin{abstract}
Penelitian ini dilakukan untuk memecahkan masalah siswa dalam kemampuan berbicara. Tujuan dari penelitian ini adalah: mendeskripsikan kemampuan berbicara siswa dengan menggunakan teknik wawancara di kelas XI SMA Negeri 3 Padangsidimpuan dan untuk mengetahui faktorfaktor yang mempengaruhi kemampuan berbicara siswa dengan menggunakan teknik wawancara pada kelas XI SMA Negeri 3 Padangsidimpuan. Metodologi penelitian yang digunakan dalam penelitian ini adalah penelitian tindakan kelas dengan menerapkan desain Hopkins yang terdiri dari empat tahap. Itu adalah perencanaan, tindakan, pengamatan, dan refleksi. Untuk mengatasi masalah siswa dalam berbicara peneliti menerapkan teknik wawancara. Peneliti menggunakan dua siklus, setiap siklus terdiri dari tiga pertemuan. Apalagi peserta penelitian ini adalah kelas XI IPA-2 (38 siswa) dan ada kolaborasi dengan guru bahasa Inggris. Sedangkan data diturunkan antara tes berbicara, observasi, dan wawancara. Kehamilan siswa di latar belakang masalahnya adalah 68 $(5,26 \%)$. Skor siswa pada siklus 1 adalah 65,57 (15,78\%) dan nilai siswa pada siklus 2 adalah 80,31 (94,73\%). Dari nilai rata-rata siswa di latar belakang masalah dan pada siklus 1, tidak menunjukkan perbaikan. Kemudian, peneliti terus menerus melakukan siklus 2. Berdasarkan hasil penelitian pada siklus 1 dan siklus 2 , hal tersebut menunjukkan peningkatan nilai mean siswa dan persentase siswa. Jadi, peningkatan kemampuan berbicara siswa dengan menggunakan teknik wawancara sangat baik kategori (sangat tinggi). Masalah siswa dalam aksen sulit diucapkan katakata. Permasalahan dalam tatabahasa sulit dilakukan dalam membangun kalimat dan menggunakan kata kerja bantu. Masalah dalam kosa kata sulit dicari kata-kata yang tepat. Soal kelancaran sulit dikelompokkan kata-kata. Masalah dalam pemahaman sulit dalam memahami kata-kata. Soal aksen dipecahkan dengan memotivasi mereka dalam melatih pengucapannya. Permasalahan dalam tatabahasa dipecahkan dengan memberikan penjelasan lebih banyak tentang konteks bahasa dan kata kerja axuliary. Masalah dalam kosakata dipecahkan dengan memberi tip dalam menghafal kosa kata dan memberi kosa kata yang berkaitan dengan materi pembelajaran. Masalah dalam kelancaran dipecahkan dengan memotivasi mereka dan memberi pengisi dalam pidato mereka. Masalah dalam pemahaman dipecahkan dengan memotivasi mereka untuk menghafal kosakata sehingga bisa mengerti makna kalimat atau pertanyaan.
\end{abstract}

Keyword: Speaking, Interview and SMA 


\section{A. INTRODUCTION}

Speaking is one of skill in English. It is very important as an ability to speak fluently not only knowledge of language features, but also the ability to process information and language. The next, it is important as the interactive process of conducting meaning. The last, it is important for career success.

The first, students' speaking ability was unsatisfactory. Based on the constitution of National Education System, passing grade of English in senior high school was 75 for all subjects and skill included speaking skill. However, the data found in SMA Negeri 3 Padangsidimpuan asserted that the score of students' speaking ability of grade XI were about $65-75 .{ }^{1}$ Five people got score sixty five. Three people got score sixty six. Eight people got score sixty seven. Sixteen people got score sixty eight. Three people got score seventy. One people got score seventy two. Two people got score seventy five. So, the average of students' speaking ability is $68(5.26 \%)$. Students' speaking ability does not fulfill the expectation.

The second, students' vocabulary and grammar were low. Their vocabulary and grammar mastery were still less because most students could not explain and generated their statement and their opinion. When they were ordered to express their arguments about the certain topic in English, they could not describe it correctly. They had difficulties to express their ideas in English.

The third, students still used their mother tongue and combined with Indonesian language when they studied English. They interacted and communicated to other people with their mother tongue and Indonesian language wherever they were. They also often used Indonesian language when they discussed about English in the classroom. It made the students difficultt in practicing English.

The fourth, students' motivation in speaking English was low. Based on private interview and information from the English teacher Mr. Syarifuddin Siregar said that one of problem on students' speaking ability was low motivation in studying English. ${ }^{2}$ It was happened because the students' economic factor. The students' parents financial were low. When the English teacher made English course (additional learning) for students in the school, most people did not attend

\footnotetext{
${ }^{1}$ Buku Kumpulan Nilai SMA Negeri 3 Padangsidimpuan, Private Document in 2014.

${ }^{2}$ Mr. Syarifuddin Siregar, Private Interview with the English Teacher, (Padangsidimpuan: SMA Negeri 3 Padangsidimpuan, at $7^{\text {th }}$ Novemver, 2014).
} 
for studying because they helped their parents to work. It was one of problem that effected to students, especially to their motivation in speaking English and practicing English.

The fifth, teacher's strategy was less suitable in teaching speaking skill in the classroom. The teacher used drill and practice method in teaching speaking. Drill and practice method is one of good strategy in teaching learning, especially to get the students' understanding. But it was less suitable to improve students' speaking ability in the classroom. The students were still passive in the classroom without response from them. They seldom gave participation when they studied English in the classroom.

Furthermore the problems above might be solved by the teacher. Its purposes were to solve the problems in the classroom, to solve or to avoid weakness of students, and to improve students' speaking ability. In solving the problems, we needed some ways or techniques. There were nine communicative fluency activities for language teaching, they were: interview, guessing games, jigsaw tasks, ranking exercises, discussions, value clarification, and problem solving activities, role play, and simulation technique. ${ }^{3}$

Second, Interview technique has not ever been used by the teacher in teaching speaking skill in the classroom. The most of teachers often used discussion method and drill and practice method in teaching English. Sometimes the teachers did not specify the methods in teaching listening, reading, writing, especially in teaching speaking.

Based on the statements above, the researcher was interested to apply this technique to teach and to overcome the students' problems in speaking at the eleventh year students of SMA Negeri 3 Padangsidimpuan in order to improve their ability in speaking through the title "Improving Students' Speaking Ability by Using Interview Technique at Grade XI SMA Negeri 3 Padangsidimpuan.

\section{B. The Objectives of the Research}

There were two objectives of the research, as follow:

\footnotetext{
${ }^{3}$ H. Douglas Brown, Teaching by Principle: An Interactive Approach to Language Pedagogy, (New Jersey: Englewood Cliffs, 1994), p. 279.
} 
1. To describe the improvement of students' speaking ability by using interview technique at grade XI SMA Negeri 3 Padangsidimpuan.

2. To identify the factors which influence students' speaking ability by using iinterview ttechnique at grade XI SMA Negeri 3 Padangsidimpuan.

\section{Theoretical Description}

\section{General Concept of Interview Technique}

\section{a. Definition of Interview Technique}

Interview technique is one of technique in teaching speaking. It is one of the effectivetechniques. Brown stated that Interview technique is one of interactive technique in teaching speaking or in teaching oral communication skill.4 It is an interactional relationship between informant and interviewer are engaged in an ongoing process of making meaning.

From the explanation above, it could be concluded that interview technique is one of interactive technique in teaching speaking skill as interactional relationship where is the informant and interviewer are engaged in an ongoing process of making meaning. It is a meeting of two persons to exchange information and idea through question and responses, the aim is to increase the students' language.

\section{b. Kinds of Interview Question}

Patton stated that there are six kinds of interview question, as follow:

1) Question about experience.

2) Question about opinion.

3) Question about knowledge.

4) Question about sense.

5) Question about background or demography. ${ }^{5}$

\section{c. Types of Interview}

Lestriana said that there are four types of interview, as follow: ${ }^{6}$

\footnotetext{
${ }^{4}$ H. Douglas Brown, Op. Cit., p. 279.

${ }^{5}$ Sugiyono, Op. Cit., p. 235-236.
} 
1) Informal conversational interview

No pretermined question are asked, in order to remain as open and adaptable as possible to the interview's nature and priorities: during the interview the interviewer "goes with the flow."

2) General interview guide approach

Intended to ensure that the same general areas of information are collected from each interviewee; this provide more focus than the conversational approach, but still allows a degree of freedom and adptability in getting the information from the interviewee.

3) Standardized, open-ended interview

The same open-ended questions are asked to all interviewees; this approach facilitates faster interviews that can be more aesily analyzed and compared.

4) Closed, fixed-response interview

All interviewees are asked the same questions and asked to choose answers from among the same set of alternatives. This format is useful for those not practiced in interviewing. Beside of interview steps or procedure above, interview also have types of interview.

\section{General Concept of Speaking Ability}

\section{a. Definition of Speaking Ability}

In defining speaking, many experts give explanation about speaking. The first, Ubaydillah stated that speaking is one of basic competence. ${ }^{7}$ Based on Competence Based Curriculum speaking is one of the four basic competences that the students should gain well. It has an important role in communication. Speaking can find in spoken cycle especially in Joint Construction of Text Stage. It is a language skill that is developed in child life, which is produced by listening skill, and at period speaking skill is learned.

\footnotetext{
${ }^{6}$ Listriana, Teaching Speaking Skill through Interview at the Eight Grade Students of SMP PGRI 9 Denpasar in Academic Year 2013/2014, (Unpublished Thesis), (Denpasar: Mahasaraswati Denpasar University, 2014),p. 10-11.

7 Ubaydillah Ibnu Sholihin, "Defenition of Speaking Skill", (www.blogspot.com, accessed at November $23^{\text {rd }}, 2014$ retrieved on 08:20 pm.)
} 
Speaking is used for many different purposes, and each purpose involves different skills. The ability to speak a second or foreign language well is a very complex task if we try to understand the nature of what appears to be involved. When we use casual conversation, for example, our purposes may be to make social contact with people to establish rapport, or to engage in the harmless chitchat that occupies much of the time we spend with friends. ${ }^{8}$

\section{b. Proficiency Level of Speaking}

Pproficiency levels of speaking based ACTFL Proficiency Guidelines in Brown, as follow: ${ }^{9}$

\section{Proficiency Level of Speaking}

\begin{tabular}{|c|c|}
\hline Level & Generic Description- Speaking \\
\hline Novice & $\begin{array}{l}\text { The novice level is characterized by the ability to } \\
\text { communication minimally with learned material. }\end{array}$ \\
\hline Novice low & $\begin{array}{l}\text { Oral production consists of isolated words and perhaps } \\
\text { a few high-frequency phases. Essentially no functional } \\
\text { communicative ability. }\end{array}$ \\
\hline Novice mid & $\begin{array}{l}\text { Oral production continues to consist of isolated words } \\
\text { and learned phrases within very predictable areas of } \\
\text { need, although quality is increased. }\end{array}$ \\
\hline $\begin{array}{l}\text { Novice } \\
\text { High }\end{array}$ & $\begin{array}{l}\text { Able to satisfy partially the requirements of basic } \\
\text { communicative exchanges by relying heavily on } \\
\text { learned utterances but occasionally expanding these } \\
\text { through simple recombinations of their elements. }\end{array}$ \\
\hline Intermediate & $\begin{array}{l}\text { The intermediate level is characterized by the speaker's } \\
\text { ability to: create with the language by combining and } \\
\text { recombining learned elements though primarily in a } \\
\text { reactive mode. Initiate, minimally sustain and close in a } \\
\text { simple way basic communicative tasks. Ask and } \\
\text { answer question. }\end{array}$ \\
\hline $\begin{array}{l}\text { Intermediate } \\
\text { low }\end{array}$ & $\begin{array}{l}\text { Able to handle successfully a limited number of } \\
\text { interactive, task-oriented and social situation. }\end{array}$ \\
\hline
\end{tabular}

${ }^{8}$ Jack C. Richards and Willy A. Renandya, Methodology in Language Teaching An Anthology of Current Practice, (Cambridge: University Press, 2002), p. 204.

${ }^{9}$ H. Douglas Brown, Op. Cit., p. 102-103. 


\begin{tabular}{|c|c|}
\hline $\begin{array}{l}\text { Intermediate } \\
\text { mid }\end{array}$ & $\begin{array}{l}\text { Able to handle successfully a variety of uncompleted, } \\
\text { basic and communicative task and social situation. }\end{array}$ \\
\hline $\begin{array}{l}\text { Intermediate } \\
\text { high }\end{array}$ & $\begin{array}{l}\text { Able to handle successfully most uncompleted } \\
\text { communicative tasks and social situations. }\end{array}$ \\
\hline Advanced & $\begin{array}{l}\text { The advanced level is characterized by the speakers } \\
\text { ability to :converse the clearly participation } \\
\text {-initiate, sustain and bring to closure a wide variety of } \\
\text { communicative task including those that require an } \\
\text { increased ability to convey meaning with diverse } \\
\text { language strategies due to a complication or an } \\
\text { unforeseen turn of events. Ssatisfy the requirement of } \\
\text { school and work situation. Nnarrate and describe with } \\
\text { paragraph-length connected discourse. }\end{array}$ \\
\hline Advanced & $\begin{array}{l}\text { Able to satisfy the requirements of everyday situations } \\
\text { and routine school and work requirements. }\end{array}$ \\
\hline $\begin{array}{l}\text { Advanced } \\
\text { plus }\end{array}$ & $\begin{array}{l}\text { Able to satisfy the requirements of a broad variety of } \\
\text { everyday, school, and work situation. }\end{array}$ \\
\hline Superior & $\begin{array}{l}\text { The superior level is characterized by the speaker's } \\
\text { ability to:participate effectively in most formal and } \\
\text { informal conversation on practical, social, professional } \\
\text { and abstract topic.Support opinion and hypothesis using } \\
\text { native-like discourse strategies. }\end{array}$ \\
\hline Superior & $\begin{array}{l}\text { Able to speak the language with sufficient accuracy to } \\
\text { participate effectively in most formal and informal } \\
\text { conversations on practical, social, professional, and } \\
\text { abstract topics. }\end{array}$ \\
\hline
\end{tabular}

\section{Research Methodology}

\section{The Research Design}

Researcher applied classroom action research (CAR) to design the research. Classroom action research was different from the other types of research. It was focused on individual or small group professional practice and it was not concern with making general statement. Gay and Eurasian stated that classroom action research is a type of practioner research that is used to 
improve the practioner's practice, action implies doing or changing something. ${ }^{10}$

\section{The Location and Schedule of the Research}

The place of the research was at SMA Negeri 3 Padangsidimpuan. It is located in PerintisKemerdekaanStreet; No.56 PadangsidimpuanThis research wasstarted fromApril11 $1^{\text {th }}$ up to April $28^{\text {th }} 2015$.

\section{The Participants}

The participants in this research were the students at grade XI IPA-2, second semester in academic years 2014/2015 SMA Negeri 3 Padangsidimpuan. It consisted of 38 students. There were 18 males and 20 females. This class was chosen because the writer found the problems of speaking in this class.Then, there was also collaboration with an English teacher, Mr. Syarifuddin, Siregar as an English teacher ofSMA Negeri 3 Padangsidimpuan.

\section{The Instrument of Collecting Data}

Instrument of collecting data was important to support every research. In this research, the researcher used three instruments of collecting data, as follow:
a. Test
b. Observation
c. Interview

\section{E. Findings/Data Presentation}

\section{Students' Achievement}

Based on the related findings of this research in chapter II, the students' achievement were: the first, Rica Umrina Lubis had done a research by the title “Improving Students' Speaking Skill through Debate at SMA Negeri 1 Padangsidimpuan". She said that debate could improve students' speaking skill. It had found that the improvement of students' achievement through debate. In cycle 1 was $46.87(0 \%)$ and in cycle 2 was 77.81 (100\%). So, cycle 2 was bigger than cycle $1(100 \%>0 \%)$.

${ }^{10}$ L.R.Gay and Peter Airasian, Education Research: Competence for Analysis and Application, (USA: Prentice Hall, Inc, 2000), p. 593. 
The second, Ida Royani Hasibuan had done research by the title “Improving Students' Speaking Skill by Using Simulation Technique at Grade XI SMK Negeri 1 Padangsidimpuan". She said that simulation technique could improve students' speaking skill. In this study, it had found that the improvement of students' achievement by using simulation technique. Cycle 1 was $13(54.2 \%)$ and cycle 2 was 18 (75\%). So, cycle 2 was bigger than cycle 1 $(75 \%-54.2 \%)$.

Siti Hijrah had done research by the title "Improving Students' Speaking Ability through Song at Grade XI SMK Swasta Panca Dharma Padangsidimpuan". She said that Songs could improve students' speaking ability. It had found that the improvement of students' achievement through songs. In cycle 1 was 60.55 (27.77\%) and cycle 2 was 73.47 (86.11\%).So, cycle 2 was bigger than cycle $1(86 \%>27.77 \%)$.

In this study, researcheralso had found that the improvent of students' achievement through the title "Improving Students' Speaking Ability by Using Interview Technique at Grade XI SMA Negeri 3 Padangsidimpuan”. In cycle 1 was $65.57(15.78 \%)$ and in cycle 2 was 80.13 (94.73\%). So, cycle 2 was bigger than cycle $1(94.73 \%>15.78 \%)$.

To look the different of the result could be seen the following table:

Table 1

Comparison of Result in Relative Findings

\begin{tabular}{|c|c|c|c|}
\hline No. & The Title of Research & $\begin{array}{l}\text { Mean } \\
\text { Score }\end{array}$ & $\begin{array}{r}\text { Per } \\
\text { centage }\end{array}$ \\
\hline 1. & $\begin{array}{l}\text { Rica Umrina Lubis "Improving } \\
\text { Students' Speaking Skill through Debate at } \\
\text { SMA Negeri } 1 \text { Padangsidimpuan" }\end{array}$ & $\begin{aligned} & 46.87 \\
- & 77.81\end{aligned}$ & $\begin{array}{c}0 \%- \\
100 \%\end{array}$ \\
\hline 2. & $\begin{array}{l}\text { Researcher (Nurmadinah Hasibuan) } \\
\text { "Improving Students' Speaking Ability by } \\
\text { Using Interview Technique at Grade XI } \\
\text { SMA Negeri } 3 \text { Padangsidimpuan". }\end{array}$ & 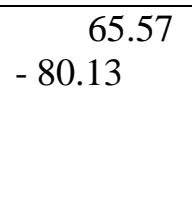 & $87^{15.7}$ \\
\hline 3. & 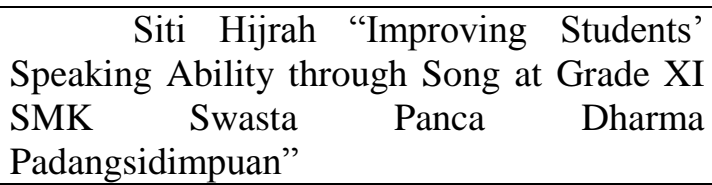 & $\begin{array}{c}60.55 \\
-73.47\end{array}$ & $\begin{array}{c}27 \% \\
-86 \%\end{array}$ \\
\hline 4. & $\begin{array}{l}\text { Ida Royani Hasibuan "Improving } \\
\text { Students' Speaking Skill by Using } \\
\text { Simulation Technique at Grade XI SMK } \\
\text { Negeri 1 Padangsidimpuan" }\end{array}$ & $13-18$ & $\begin{array}{c}54 \% \\
-75 \%\end{array}$ \\
\hline
\end{tabular}


Based on the students' achievement in the above researches, researcher could be concluded that the the first researchhad done by Rica Umrina was higher than the second, the third, and the fourth research. It could be explaned the improvement based on the classification quality of students' score in chapter III. The first research had done by Rica Umrina was categoried very good, the percentages of cycle 1 and cycle 2 ware $0 \%-100 \%$. The second research had done by researcher (Nurmadinah Hasibuan) was categoried very good, the percentage of cycle 1 and cycle 2 were $15.78 \%-94.73 \%$. The third research had done by Siti Hijrah was also categoried very good, the percentages og cycle one and cycle 2 ware $27 \%-86 \%$. The fourt research had done by Ida Royani Hasibuan was categoried good. The percentage of cycle 1 and cycle 2 were $54 \%-75 \%$. So, the implementation of the above techniques could improve students' speaking skill in the schools. The result of the students' achievement shown the high improvement.

\section{Influencing Factors}

Researcher has found some problems of students in speaking ability and also in related findings that have been done by the researchers.

Researcher also had found some problems of students in speaking ability, they were; students were difficult in pronouncing the English word because studentshad never trained their pronounciation so their tounge was stiff and they were also less interested in speaking English; students were difficult in building sentences and using auxiliary verb with the subject; students were difficult in searching adequate words and mastering the specificwords; students were difficult in speaking English fluently because their utterances low, hesitant and jerky, occasionally hasitant and grouping words; and students were difficult in understanding or uttering words because their mastery of vocabulary were still limited.

Based the above problems, it can be concluded that there were some similarities and differences problems. The similarities of above problems were; in the first and the second related finding had the same problems in accents, grammar, vocabulary, and fluency. The differences of above problems were; in 
the first related finding, researcher had not found problem in comprehension and just found problems in accent, grammar, vocabulary, and fluency; in the second related finding, researcher had found problem in arranging the seat formation and had not found problem in comprehension; in the third related finding, researcher just found problems in vocabulary, fluency, and internal factor such as students' confidence and students' motivation.

Researcher has also found some solution of the students' problems in speaking ability and also in related findings that have been done by the researchers.

The first of related finding, the solutions of students' speaking skill that found by the researcher (teacher) were; the teacher mentioned the vocabulary that they did not know and the teacher gave more motivation to them.

The second of related finding, the solution of students' speaking skill that found by the researcher (teacher) were; teacher arranged seat formation appropriately; teacher understood them that they had their own time in simulation; teacher motivated them to use suitable word longer by using some conjunction or clauses; teacher clarified obligatively having batakness reflected teir bad attitude. Using hand while speaking was admitted but not to be function as sign language; and teacher motivated students to use optimally the instrument tho help vocabulary enrichment including how to pronounciate the word.

The third of related finding, the solution of students' speaking skill that found by the researcher (teacher) were; teacher motivated students in learnng English; teacher gave some alternatives to memorize vocabulary and gave vocabularies that they did not know; and students motivated them in speaking well and fluently.

Researcher also found some solutions of students' problems in speaking ability, they were; researcher gave ways in training their pronounciation such as listening English song or English movie to accustom them heard the English word and reading English book ordinary little by little; researcher motivated them to be diligent in training their pronounciation and gave them illustration if someone could speak English and could not speak English; in teaching learning 
process, researcher gave the some vocabularies especially the difficult words that they didn't know before starting the next meeting; researcher gave more explanation about the language context that targetted in the next meeting clearly; researcher reclarified the usage of auxiliary verb in the sentences and motivated them to practice their knowledge in their life; researcher gave tips or methods to memorize vocabularies such as semantic mapping, using pictures, and using key words; researcher motivated them to train their speaking and to record their speech so that the could know about their abilty; researcher gave peer help and necessary instrument when learning process was running such as using filler in their speech so that their speech became coherence and understandable speech; and researcher motivated students to memorize more vocabularies.

\section{F. Conclusion}

From the result of this research, researcher can be concluded that:

1. Interview technique can improve students' speaking ability at grade XI SMA Negeri 3 Padangsidimpuan. Based onthe analyzing ofresearch data, the mean score of students' speaking ability in cycle 1 is $65.57(15.78 \%)$ and cycle 2 is 80.13 (94.73\%). The students' improvement can be categorized into very high improvement (very good).

2. Some factors that influence students' speaking ability by using interview technique are students' motivation, students' interest, students' enthusiasm in learning process, teacher's ways in teaching, teacher's ways in explaining learning material, teacher's ways in motivating students, and teacher's ways in controlling the classroom.

\section{G. Suggestions}

Based on the above conclusion, researcher has some suggestions as below:

1. Based on the first conclusion, students' speaking can improve by using interview technique at grade XI SMA Negeri 3 Padangsidimpuan, researcher suggests to the teacher to apply this technique in teaching speaking skill by looking at the students' problem in speaking ability, give solutions to the students' problem, and looking at the teacher's ways in teaching. To another 
researchers, the researcher suggeststo improve students' speaking ability by using interview techniqueuntil $100 \%$. The other researcher can use the other creative solutions in solving students' speaking ability and can do research in two or three cycles so that the improvement can achieve until $100 \%$.

2. Based on the second conclusion, in improving students' speaking ability there are some factors that influence students' speaking ability by using interview technique, the researcher suggests to the teacher and to another researchers who wants to do the same research can controll and look at the factors that influence students' speaking ability by using interview technique. The teacher and the another researchers must give the good motivation, increase students' interest, and increase students' enthusiasm in learning process. Beside it, the teacher and the another researchers must be creative in designing teaching learning process, in explaining learning material, in motivating students, and in controlling the classroom so that students' speaking ability can improve with the very high improvement.

\section{REFERENCES}

Ahmad Sabri, Strategi Belajar Mengajar dan Micro Teaching, Jakarta: Ciputat Press, 2005.

Bachman, Lyle F., Fundamental Consideration in Language Testing, New York: Oxford University Press, 1990.

Brown, H. Douglas, Teaching by Principle: An Interactive Approach to Language Pedagogy, New Jersey: Englewood Cliffs, 1994.

Burns, Anne, Doing Action Research in English Language Teaching, New York: Routledge, 2010.

Chamot, Anna Uhl, The Learning Strategies Handbook, Longman: Addison Wesly Longman, Inc, 1999.

Chaney, A. L. and T.L. Burke, Teaching Oral Communication in Grades K-8, Boston: Allyn\& Bacon, 1998.

Creswell, John W., Research Design: Qualitative, Qualitative, and Mixed Methods Approaches, USA: Sage Publication, 2003.

Freseman, Diane Larsen, Technique and Principles in Language Teaching As a Second Language, New York: Oxford University Press.

Gay, L.R. and Peter Airasian, Education Research: Competence for Analysis and Application, USA: Prentice Hall, Inc, 2000.

Harmer, Jeremy, The Practice of English Language Teaching, London: Longman, 2001. Hartono, Statistik: UntukPenelitian, Yogyakarta: PustakaPelajar Offset, 2004. 
Hasibuan, Ida Royani, "Improving Students' Speaking Skill by Using Simulation Technique at Grade XI SMK Negeri 1 Padangsidimpuan in 2012 Academic Year", (Unpublished Thesis), Padangsidimpuan: STAIN, 2012.

Hornby, A.S., Oxford Advanced Learner's Dictionary, New York: Oxford University Press, 1995.

Hughes, Arthur, Testing for Language Teachers, USA: Cambridge University Press, 1990.

Istarani, 58 Model Pembelajaran Inovatif, Medan: Mediapersada, 2012.

Johnson, Andrew P., A Short Guide to Action Research Second Edition,America: Pearson Education, 2005.

Listriyana, Teaching Speaking Skill through Interview at the Eight Grade Students of SMP PGRI 9 Denpasar in Academic Year 2013/2014, (Unpublished Thesis), Denpasar: Mahasaraswati Denpasar University, 2014.

Muhammad Muhsin Khan dan Muhammad Taqi-ud-Din Al-Hilali, The Noble Qur'an, Jakarta: Al-Huda, Kelompok Gema Insani, 2014.

Mukoroli, Joseph, "Effective Vocabulary Teaching Strategies for The English For Academic Purposes ESL Classroom" www.digitalcollections.sit.edu, accessedatNovemver $23^{\text {rd }}, 2014$ retrieved on 08: $20 \mathrm{pm}$.

Nunan, David, Designing Tasks for the Communicative Classroom,Cambridge: Cambridge University Press, 1989.

Ommaley, J. Michael, Authentic Assessment for English Language Learners, USA: Addison- Wesley Publishing Company, 1996.

Rangkuti, Ahmad Nizar, Metode Penelitian Pendidikan: Pendekatan Kuantitatif, Kualitatif, PTK, dan Penelitian Pengembangan, Bandung: Citapustaka Media, 2014.

Richards, Jack C. and Willy A. Renandya, Methodology in Language Teaching An Anthology of Current Practice, Cambridge: University Press, 2002.

Riduwan, Belajar MudahPenelitian Untuk Guru-Karyawan dan Penelitian Pemula, Bandung: Penerbit Alfabeta, 2012.

Slavin, Robert E., Cooperative Learning: Theory, Research, and Practice, Second Edition, London: Allyn And Bacon, 1995.

Sugiyono, Metode Penelitian Kuatitatif, Kualitatif, dan $R \& D$, Bandung: Penerbit Al Fabeta, 2009.

Syafei,Anas, Pronounciation:Theory and Practice, Jakarta: Depdikbud, 1988.

Turk,Chistopher, Effective Speaking Communicating in Speech, British: British Library Publication Data, 1985.

Ubaydillah Ibnu Sholihin, "Defenition of Speaking Skill", www.blogspot.com, accessed at November $23^{\text {rd }}, 2014$ retrieved on 08:20 pm.

Verderber, Rudolph F. and Kathleen S. Verderber, The Challenge of Effective Speaking, USA: University of America, 2008.

Weir, Cyril J., Communicative Language Testing, (New York: Prentice Hall, 1990), p. 76.

Wina Sanjaya, Penelitian Tindakan Kelas, Jakarta: Kencana, 2009. 